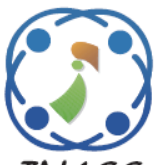

\title{
Experimental Study on Removal of Chromium by using Cow Dung as Low Cost Adsorbents
}

\author{
Ayyappan Thangavel ${ }^{1 *}$ \\ Elangovan Gopal ${ }^{2}$ \\ ${ }^{1}$ Ratnavel Subramaniam College of Engineering, Dindigul, Tamilnadu, India \\ ${ }^{2}$ University college of Engineering, Pattukottai, Tamilnadu, India \\ * Corresponding author's Email: prayyappan@gmail.com
}

\begin{abstract}
In apparent, the intension is removal of chromium using cow dung as low cost adsorbents from the industrial wastewater. Chromium ( $\mathrm{Cr}$ ) is one of the most toxic substances and is introduced into the environment through a variety of industrial activities. In order to remove the chromium from the contaminated water there are lot of methods available, even though they are not in natural way. In the paper naturally availing material like Cow dung ash is used to remove the chromium by adsorbent method. Since the collected chromium contaminated waste water from the industry will have only a particular $\mathrm{Cr}+$ concentration and $\mathrm{pH}$ value, an aqueous solution has been prepared with unique concentration and with different $\mathrm{pH}$ values. And activated ash is added separately to the aqueous solution with different dosages and varying contact periods. From the investigation and interpretation of results it has been noted that the Cow dung ash has effectively removed the chromium content when it was added $6 \mathrm{~g} / \mathrm{l}$ to the $1000 \mathrm{ml}$ of aqueous solution. In the view of contact time of the adsorbent, 3 hours of period been an ideal one and $\mathrm{pH}$ doesn't had a significant effect.
\end{abstract}

Keywords: Chromium (Cr), Cow dung, Aqueous solution, Spectrometer, pH meter.

\section{Introduction}

Nowadays, the chemical contamination of water by aromatic molecules from industrial waste represents a topic of concern. Among all the treatments proposed, adsorption using sorbents is one of the most commonly applied methods since it is an effective, efficient and economic method for water decontamination [1] Chromium $(\mathrm{Cr})$ is considered to be the top most priority toxic pollutant. Chromium metal in its natural form is found to exist in two states: $\mathrm{Cr}$ (III) and Cr (VI). Hexavalent chromium is 100 times more toxic than trivalent chromium and due to its toxicological and carcinogenic consequences; it is likely to cause detrimental health hazards [2]. Cr (VI) is a toxic metal and must be removed from wastewater before it can be discharged. $\mathrm{Cr}$ (II), $\mathrm{Cr}$ (III) and $\mathrm{Cr}$ (VI) are the three oxidation states for chromium in nature, but only the last two are stable. $\mathrm{Cr}$ (III) is stable and less toxic or nontoxic, and is considered an essential element for the good health and nutrition of many organisms [3]. The recovery of chromium (III) from the leather wastes is justifiable both ecologically and economically. First of all, it reduces a risk of contamination of environment by compounds of chromium and may prevent loses of the large amounts of the collagen proteins contained in such wastes [4]. For this reason, batch kinetic, as well as equilibrium sorption and desorption experiments were conducted using As (V), $\mathrm{Cr}$ (III) and $\mathrm{Cr}$ (VI) as adsorbates. The biochars used were derived from rice husk, the organic fraction of municipal solid wastes and sewage sludge [5]. Chromium forms three common oxidation states in its compounds, +2 , +3 , and +6 . The +3 and +6 oxidation states are the most commonly observed in chromium compounds, whereas $+1,+4$, and +5 states are rare. The most prominent example of toxic chromium is hexavalent chromium (Cr (VI) [6]. chromium metal can be removed from wastewater by many methods, for example, reduction, precipitation, electrodialysis, ion exchange, evaporation, reverse osmosis, solvent extraction and adsorption [7]. The metal chromium is used mainly for making steel and other alloys. Chromium compounds, in either the chromium (III) 
or chromium (VI) forms, are used for chrome plating, the manufacture of dyes and pigments, leather and wood preservation, and treatment of cooling tower water [8]. Chromium affects human physiology by accumulating in food chain and cause several ailments Human exposure to $\mathrm{Cr}$ (VI) compounds is associated with a higher incidence of respiratory cancers [9]. The effluents produced from various manufacturing industries contain Chromium and Cadmium compounds in alarming proportion. The increasing awareness of environmental pollution has led to a quest for effective and innovative treatment methods. Various methods of treatments such as chemical precipitation, electrodialysis, membrane process, liquid extraction and ion exchange have been employed for the removal of this heavy metal [10]. For the removal of heavy metal from the aqueous milieu, various methods such as chemical precipitation, electrodialysis, membrane process, liquid extraction and ion exchange have been employed [11]. Biogas is a commonly used bio-fuel around the globe and is generated through an environmental friendly process of anaerobic digestion or the fermentation of biodegradable matters such as biomass, manure, sewage, municipal waste, rubbish dumps, septic tank, green waste and energy crops with a stable product for agricultural purposes without any detrimental effect on the environment [12]. Bio fertilizers contain microorganisms that help plants to grow by increasing the quantity of nutrients. Since these fertilizers contain living microorganisms, it increases or promotes the supply of important nutrients crucial for the overall productivity of the soil [13].The use of biogas is capable of providing a special impetus in both rural and urban areas. Biogas plant can be built by using materials which are locally available in most developing countries like Nigeria [14]. Cow dung is utilized for removing the chromium metal. Cow dung can be defined as the undigested residue of consumed food material being excreted by herbivorous bovine animal species. Being a mixture of faeces and urine in the ratio of $3: 1$, it mainly consists of lignin, cellulose and hemicelluloses [15]. Several treatment techniques are available for chromium removal, the most commonly used ones are adsorption, reduction and precipitation, ion exchange and reverse osmosis. Among these methods, adsorption is found to be simple, cost effective and a versatile method for removing heavy metals [16]. Industrial activities like electroplating, metal cleaning and dyeing processing, cement and leather tanning are the major sectors that play role in releasing chromium into the environment [17]. Conventional methods for removing $\mathrm{Cr}$ (VI) ions from industrial wastewater are expensive. Recently, numerous approaches have been studied for the development of the cheaper and more effective technologies for the removal of the heavy metals esp. Cr (VI) from the wastewater [18].The main objective of this research work investigate the effect of cow dung over the removal of chromium, the cow dung which is collected has been dried and burned with high temperature resulting To prepare low cost adsorbent materials from the locally available waste materials by applying suitable methods of preparation. The availability in plenty is the prime choice of choosing this particular waste to develop low cost absorbent. Main advantage of this work is utilized low cost materials to remove the chromium dosage. In section 2 there is an elaborate description regarding the literary reviews. Section 3 is rich with colorful data on the experimental analysis. In section 4 discuss the various tests conducted with different level of $\mathrm{pH}$ values. Section ends with a befitting conclusion.

\section{Literature Review}

In 2016 A. T. Ojedokun et al. [19] had proposed the presence of heavy metals (e.g., $\mathrm{Zn}, \mathrm{Cu}, \mathrm{Pb}, \mathrm{Ni}$, $\mathrm{Cd}$, etc.) in aqueous solutions constitutes a major environmental problem. The previous work represented the review of the recently published literature discussing the use of cow dung as adsorbent for the removal of metal ions from aqueous solution using batch experiments. The potential health and environmental hazards of metal ions in addition to the kinetic and isothermal models usually assessed to fit the biosorption experimental data were also reviewed. Conclusively, it had been established that the use of cow dung is also called as the promising adsorbent in the removal of heavy metals from waste waters and environment.

In $2016 \mathrm{~K}$. Kaur et al. [20] had proposed the application of cow dung ash was assessed for the removal of organic contamination from the wastewater using land fill leachate of known Chemical Oxygen Demand (COD) concentration in batch mode. The effect of various parameters like adsorbents dose, time, $\mathrm{pH}$ and temperature had been investigated. Results indicate that up to $79 \%$ removal of COD could be achieved using activated cow dung ash (ACA) at optimum temperature of $30^{\circ} \mathrm{C}$ at $\mathrm{pH} 6.0$ using $20 \mathrm{~g} / \mathrm{L}$ dose in 120 minute, whereas cow dung ash (CA) shows $66 \%$ removal at $\mathrm{pH} 8.0 \mathrm{using} 20 \mathrm{~g} / \mathrm{L}$ dose, also in 120 minutes. Data also showed that ACA exhibited 
11-13\% better removal efficiency than CA. COD removal efficiency of various adsorbents was also compared and it had been found that ACA offered significantly higher efficiency. Freundlich and Langmuir adsorption isotherms were also applied, which depicts good correlations (0.921 and (0.976) with the experimental data.

In 2014 M. I. Alfa et al. [21] had proposed the efficiency of the mesophilic bio digestion process in the stabilization and sanitization of cow dung and chicken droppings. Six (6) kg each of cow dung and chicken droppings were collected fresh and free from impurities, pre-fermented, mixed with water in the ratio $1: 1 \mathrm{w} / \mathrm{v}$ to form slurry, fed into the respective reactors and digested for 30 days at an average ambient temperature of 30degree centigrade. The $\mathrm{pH}$ of the medium fluctuated between 6.5 and 8.0. The analysis of the feedstock and effluent of the digesters showed that a total solids reduction of $75.3 \%$ and $60.1 \%$ were recorded for cow dung and chicken droppings while the reduction in total coliforms had about $95 \%$ and $70 \%$ respectively for the dung and droppings. Microbial analysis of the bio fertilizer produced reveals both aerobic and anaerobic organisms which include species of Pseudomonas, Klebsiella, Clostridium, Bacillus, Bacteroides, Salmonella, Penicillum and Aspergillus. Escherichia coliand Shigellaspp were removed while species of Salmonella and Klebsiella were still presented in the digestate.

In 2014 P. Mullai et al. [22] had proposed the presence of heavy metals in water supplies and wastewater threatens the environment and the health of humans. The adsorption of chromium (VI) onto cow dung ash, a bio-organic waste had been investigated in a batch reactor under two different conditions, namely, initial metal ion concentration and adsorbent dosages. For the five different initial metal ion concentrations such as 500, 600, 800, 900, $1000 \mathrm{mg} / \mathrm{L}$, the steady state values of chromium removal efficiency were $100,83.33,88.09,94.3$ and $96 \%$, respectively, using $20 \mathrm{~g}$ of cow dung ash under shaking at the end of 3rdh. The equilibrium of the process was found to fit into the two well-known adsorption models, Freundlich and Langmuir. The results obtained in the previous study revealed the potential application of the cow dung ash in the removal of metal ions from the aqueous solution.

In 2013 G. Corro et al. [23] had proposed the biogas and had been produced by the co-digestion of coffee-pulp and cow-dung mixture under solar radiation. Gas chromatography and FTIR spectroscopy were used to analyze the chemical compositions of the generated biogas and its post combustion emissions. From the first month of codigestion at mesophylic conditions, methane content in the biogas attains $50 \%$ of the yield. This content increased up to $60 \%$ and remained almost constant for at least 8 months of further digestion. The FTIR gas spectroscopy analysis revealed the presence of over 70 chemical compounds in the biogas generated after 4 months of co-digestion along with several compounds hazardous to environment and animal health like isocyanic acid, and bromomethane. Combustion emission of the biogas contained several components like $\mathrm{CH} 4, \mathrm{C} 3 \mathrm{H} 8, \mathrm{CO}$, $\mathrm{SO} 2, \mathrm{HI}$, and probably $\mathrm{Br} 2$ which are strongly harmful to human and animal health.

In 2012 A. Ounnar et al. [24] had proposed the anaerobic digestion offers an advantageous alternative to land filling, incineration and composting since it is considered as the most appropriate treatment solution. Indeed, the biogas naturally produced by the fermentation of organic waste into anaerobic digesters, contains between 40 and $60 \%$ of methane, which gives it fuel character and its valorization allows energy conservation while protecting the environment by reducing the greenhouse gases emission. The main aim of the literature explained to popularize the technique of organic waste bio methanisation or anaerobic digestion in order to produce renewable energy and cleaner environment through the exploitation of research results. The above process supported to the experimental results obtained in the laboratory. The mesophilic anaerobic digestion of cow dung, into an experimental digester of 800 liters capacity, had produced $26.478 \mathrm{~m}^{3}$ of biogas for 77 days with an average optimal. These results are hopeful for the use of cattle wastes mass available in Algeria, or even household wastes.

\section{Experimental Investigation}

\subsection{Materials Used}

In the paper work explores the possibility of using the natural waste such as dried cow dung. The availability in plenty is the prime choice of choosing this particular waste to develop low cost absorbent. The general properties of dried cow dung are introduced in below section.

\subsubsection{Properties of Cow Dung}

- In many parts of the developing world and in the past in mountain regions caked and dried cow dung is used as fuel. 
- Cow dung may also be collected and used to produce biogas to generate electricity and heat.

- The gas is rich in methane and is used in rural areas to provide a renewable and stable source of electricity.

- In villages, the cow dung is burned to repel mosquitoes.

- In cold places, cow dung is used to line the walls of rustic houses as a cheap thermal insulator.

- Cow dung is also an optional ingredient in the manufacture of adobe mud brick housing depending on the availability of materials at hand.

\subsection{Low Cost Adsorbent Preparation}

The cow dung was collected around the neighbourhood of R.V.S. college of Engineering, Dindigul. The detailed procedure for the activation of natural waste as low cost absorbent is summarized below.

\subsubsection{Activated Cow Dung}

The dried cow dung is treated with concentrated $\mathrm{H}_{2} \mathrm{SO}_{4}$ in the ratio of 1:1 and kept in the oven for $24 \mathrm{hrs}$. Then the activated cow dung is washed with the distilled water to remove the free acids and dried for few hours. The Figure 1 shows the raw cow dung as collected and the final activated powder material ready to be used as absorbent.
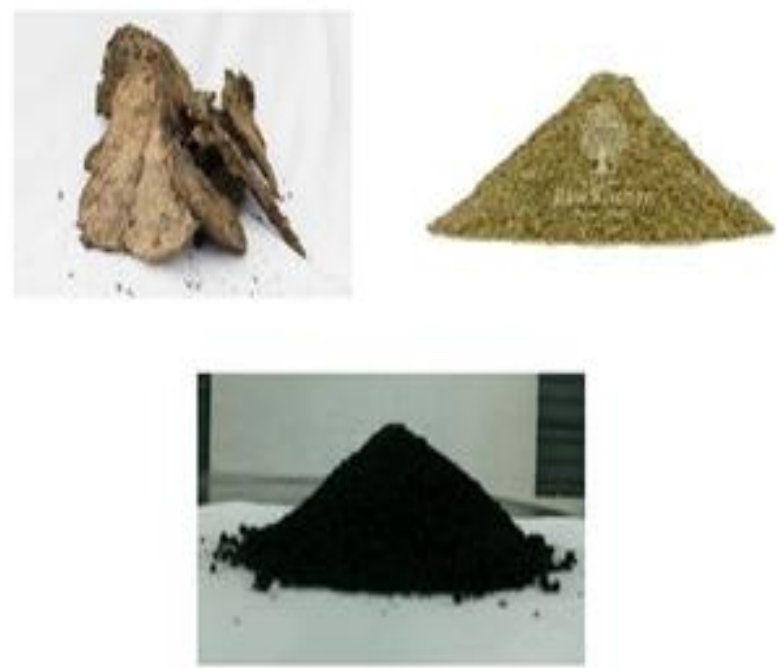

Figure.1 Cow Dung Sample Preparation

\subsection{Preparation of Aqueous Solution}

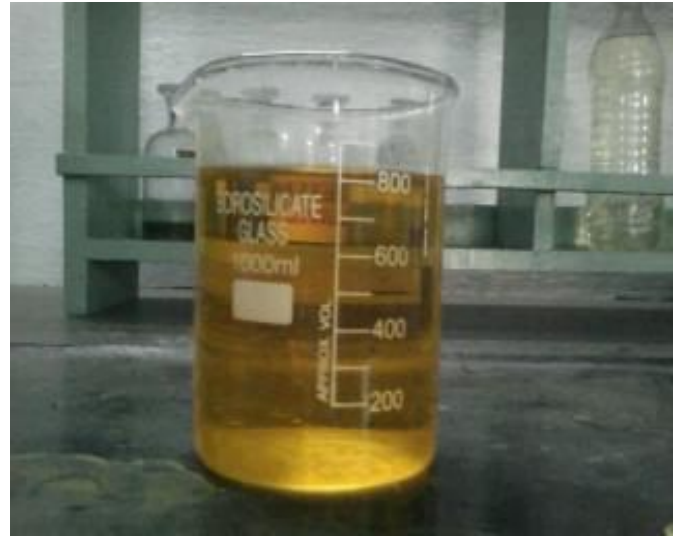

Figure.2 Aqueous Solution

In this research work, the aqueous solution is employed rather than the collected chromium contaminated waste water from the industry to study the influence of proposed activated cow dung. The reason for the use of aqueous solution for this research study is, the collected chromium contaminated waste water from the industry will have only a particular $\mathrm{Cr}^{+}$concentration and $\mathrm{p}^{\mathrm{H}}$ value. A stock solution of $\mathrm{Cr}(\mathrm{VI})$ is prepared by dissolving $2.8287 \mathrm{~g}$ of $\mathrm{K}_{2} \mathrm{Cr}_{2} \mathrm{O}_{7}$ in $1000 \mathrm{ml}$ of water. The prepared solution is diluted as required to obtain standard solution. Initial concentration of prepared solution is $1000 \mathrm{ppm}$. The prepared aqueous solution is shown in Figure 2.

To study the presence of chromium in the prepared solution a Confirmatory Test is carried out. In the $10 \mathrm{ml}$ of prepared aqueous solution, we add $1 \mathrm{ml}$ of Hydrogen Peroxide $\left(\mathrm{H}_{2} \mathrm{O}_{2}\right)$ and add $2 \mathrm{ml}$ of Sodium Hydroxide drop wise. Then heat solution in the boiling water bath for a several minutes. The presence of Chromium on the solution is confirmed through the change in solution as yellow colour $\left(\mathrm{Cr}_{4}^{2-}\right)$.

\subsection{Preliminary Test}

The use of absorbents should not significant alter the characteristics of the potable drinking water. For that, the preliminary studies such as evaluating $\mathrm{p}^{\mathrm{H}}$ value and turbidity tests were carried out in prepared aqueous solution.

\subsubsection{Evaluation of $\mathrm{p}^{\mathrm{H}}$ value}

The $\mathrm{p}^{\mathrm{H}}$ value is defined as the logarithm of reciprocal of the hydrogen ion concentration.

$$
p^{H}=-\log \left[H^{+}\right](1)
$$

$\mathrm{p}^{\mathrm{H}}$ values are calculated in powers of 10 . 


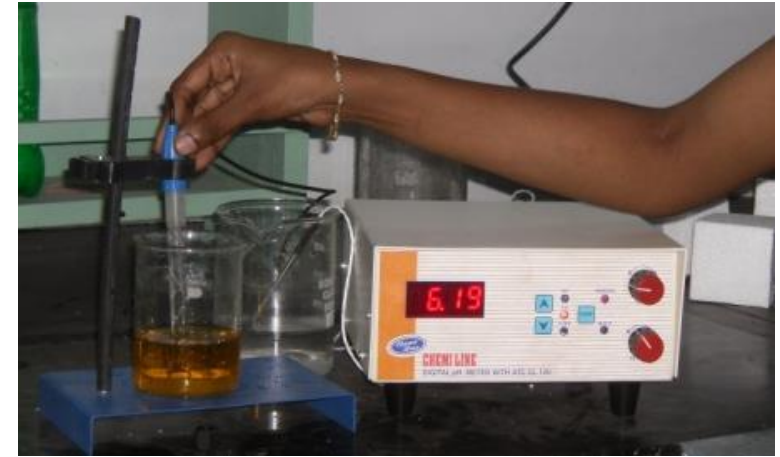

Figure. $3 \mathrm{p}^{\mathrm{H}}$ Meter

The hydrogen ion concentration of a solution with $\mathrm{p}^{\mathrm{H}} 1.0$ is 10 times larger than the hydrogen concentration in a solution with $\mathrm{p}^{\mathrm{H}}$ 2.0. When the $\mathrm{p}^{\mathrm{H}}$ is above 7 the solution is stated as basic (alkaline) and when the $\mathrm{p}^{\mathrm{H}}$ is below 7 the solution is stated as acidic. The $\mathrm{p}^{\mathrm{H}}$ of the aqueous solution was obtained a digital desktop $\mathrm{p}^{\mathrm{H}}$ meter. The read out of the
$\mathrm{p}^{\mathrm{H}}$ meter will gives direct $\mathrm{p}^{\mathrm{H}}$ value of the sample. The $\mathrm{p}^{\mathrm{H}}$ of the prepared aqueous solution is Figure 3.

\subsection{Spectrophotometer}

In this study,theSpectrophotometer is used to evaluate the concentration of chromium present in the test sample. Spectrophotometer is an instrument used for detecting metals in solution. A spectrophotometer is an instrument that measures the amount of photons (the intensity of light) absorbed after it passes through sample solution. With the spectrophotometer, the amount of a known chemical substance (concentrations) can also be determined by measuring the intensity of light detected.

Below figure 4 has been shown that the spectrophotometer working principle.

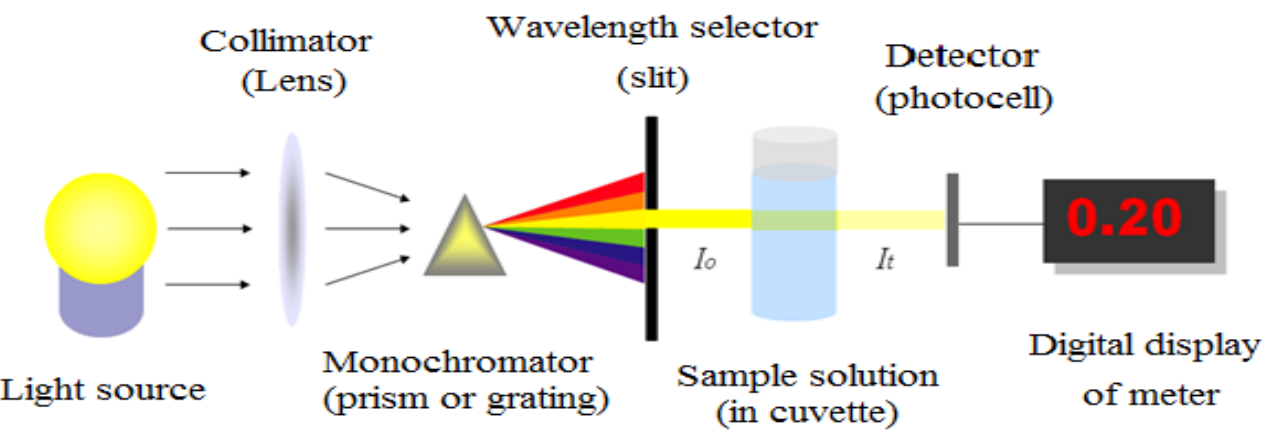

Figure.4 Spectrophotometer Working Principle

\section{Result and Discussion}

The results observed from the various tests conducted with different additives of varying percentages and different level of $\mathrm{p}^{\mathrm{H}}$ have been plotted in the graphs and tabulated with care as follows.

Table 1, 2 and 3 shows the laboratory results on the final concentration of chromium content in the aqueous solution with different dosage and different $\mathrm{pH}$ level at the varying contact periods.

Time has a huge part on the measure of $\mathrm{Cr}$ expelled. It was watched that \% evacuation of $\mathrm{Cr}$ is straightforwardly relative to time. However, the adsorption limit appears to diminish after some time since the response has a tendency to achieve harmony after there is no much increment in the adsorption.
Table 1. Final Concentration of Aqueous Solution with Different Dosage at $1 \mathrm{Hr}$

\begin{tabular}{|c|c|c|c|c|}
\hline $\begin{array}{c}\text { Contact Time } \\
\text { in Hrs }\end{array}$ & $\mathbf{p}^{\mathbf{H}}$ & $\begin{array}{c}\text { Dosag } \\
\mathbf{e}\end{array}$ & $\begin{array}{c}\text { Adsorbent } \\
\text { Values }\end{array}$ & $\begin{array}{c}\text { Final } \\
\text { Concentratio } \\
\mathbf{n}\end{array}$ \\
\hline \multirow{5}{*}{1} & 6 & 4 & 0.2361 & 2.05 \\
\cline { 2 - 5 } & 7 & 4 & 0.0566 & 0.49 \\
\cline { 2 - 5 } & 8 & 4 & 0.0825 & 0.72 \\
\cline { 2 - 5 } & 9.2 & 4 & 0.0997 & 0.87 \\
\hline \multirow{5}{*}{1} & 6 & 6 & 0.0582 & 0.51 \\
\cline { 2 - 5 } & 7 & 6 & 0.0762 & 0.66 \\
\cline { 2 - 5 } & 8 & 6 & 0.0828 & 0.72 \\
\cline { 2 - 5 } & 9.2 & 6 & 0.0713 & 0.62 \\
\hline \multirow{5}{*}{1} & 6 & 8 & 0.0621 & 0.54 \\
\cline { 2 - 5 } & 7 & 8 & 0.075 & 0.65 \\
\cline { 2 - 5 } & 8 & 8 & 0.0663 & 0.58 \\
\cline { 2 - 5 } & 9.2 & 8 & 0.0858 & 0.75 \\
\hline \multirow{5}{*}{1} & 6 & 10 & 0.0704 & 0.61 \\
\cline { 2 - 5 } & 7 & 10 & 0.0801 & 0.7 \\
\cline { 2 - 5 } & 8 & 10 & 0.1034 & 0.9 \\
\cline { 2 - 5 } & 9.2 & 10 & 0.1243 & 1.08 \\
\hline
\end{tabular}


Table 2. Final Concentration of Aqueous Solution with Different Dosage at $2 \mathrm{Hr}$

\begin{tabular}{|c|c|c|c|c|}
\hline $\begin{array}{c}\text { Contact } \\
\text { Time in Hrs }\end{array}$ & $\mathbf{p}^{\mathbf{H}}$ & Dosage & $\begin{array}{c}\text { Adsorben } \\
\mathbf{t} \text { Values }\end{array}$ & $\begin{array}{c}\text { Final } \\
\text { Concentrat } \\
\text { ion }\end{array}$ \\
\hline \multirow{4}{*}{2} & 6 & 4 & 0.0576 & 0.5 \\
\cline { 2 - 5 } & 7 & 4 & 0.0688 & 0.6 \\
\cline { 2 - 5 } & 8 & 4 & 0.032 & 0.28 \\
\cline { 2 - 5 } & 9.2 & 4 & 0.089 & 0.77 \\
\hline \multirow{4}{*}{2} & 6 & 6 & 0.0548 & 0.48 \\
\cline { 2 - 5 } & 7 & 6 & 0.0753 & 0.65 \\
\cline { 2 - 5 } & 8 & 6 & 0.0229 & 0.2 \\
\cline { 2 - 5 } & 9.2 & 6 & 0.0858 & 0.75 \\
\hline \multirow{4}{*}{2} & 6 & 8 & 1.567 & 13.63 \\
\cline { 2 - 5 } & 7 & 8 & 0.0781 & 0.68 \\
\cline { 2 - 5 } & 8 & 8 & 0.1337 & 1.16 \\
\cline { 2 - 5 } & 9.2 & 8 & 0.089 & 0.77 \\
\hline \multirow{4}{*}{2} & 6 & 10 & 0.0888 & 0.77 \\
\cline { 2 - 5 } & 7 & 10 & 0.0783 & 0.68 \\
\cline { 2 - 5 } & 8 & 10 & 0.0614 & 0.53 \\
\cline { 2 - 5 } & 9.2 & 10 & 0.0743 & 0.65 \\
\hline
\end{tabular}

Table 3. Final Concentration of Aqueous Solution with Different Dosage at $3 \mathrm{Hr}$

\begin{tabular}{|c|c|c|c|c|}
\hline $\begin{array}{c}\text { Contact Time } \\
\text { in Hrs }\end{array}$ & $\mathbf{p}^{\mathbf{H}}$ & Dosage & $\begin{array}{c}\text { Adsorbent } \\
\text { Values }\end{array}$ & $\begin{array}{c}\text { Final } \\
\text { Concentrat } \\
\text { ion }\end{array}$ \\
\hline \multirow{4}{*}{3} & 6 & 4 & 0.0549 & 0.48 \\
\hline & 7 & 4 & 0.0717 & 0.62 \\
\hline & 8 & 4 & 0.0267 & 0.23 \\
\hline & 9.2 & 4 & 0.0473 & 0.41 \\
\hline \multirow{4}{*}{3} & 6 & 6 & 0.0569 & 0.49 \\
\hline & 7 & 6 & 0.0163 & 0.14 \\
\hline & 8 & 6 & 0.0295 & 0.26 \\
\hline & 9.2 & 6 & 0.0945 & 0.82 \\
\hline \multirow{4}{*}{3} & 6 & 8 & 0.1808 & 1.57 \\
\hline & 7 & 8 & 0.2045 & 1.78 \\
\hline & 8 & 8 & 0.0399 & 0.35 \\
\hline & 9.2 & 8 & 0.0472 & 0.41 \\
\hline \multirow{4}{*}{3} & 6 & 10 & 0.2085 & 1.81 \\
\hline & 7 & 10 & 0.2038 & 1.77 \\
\hline & 8 & 10 & 0.0497 & 0.43 \\
\hline & 9.2 & 10 & 0.0521 & 0.45 \\
\hline
\end{tabular}

The underlying convergence of $\mathrm{Cr}$ additionally assumes a critical part in the adsorption wonders as it is having direct connection with sum evaluated, however the \% expelled is same in every one of the cases.

\subsection{Removal of Chromium with Varies Dosage of Cow Dung}

In the view of obtaining the effect of cow dung over the removal of chromium, the cow dung which is collected has been dried and burned with high temperature resulting as an ash has been added to the aqueous solution made with various $\mathrm{p}^{\mathrm{H}}$ levels. And the cow dung ash has been mixed with different proportions such as $4 \%, 6 \%, 8 \%$ and $10 \%$ by its dry weight to find out the optimum level of additive. In order to find out the effect of contact period over the effectiveness of chromium removal, the solution added with cow dung ash was kept in different time limits of 1 hour, 2 hours and 3 hours.

From the Figure 5 and Table 4, it has been observed that the chromium contaminant has effectively removed from the aqueous solution by adding the Cow dung as a stabilizer. In precise the chromium content removal percentage has been increased from $99.142 \%$ to $99.942 \%$ for the dosage level of $4 \%$ to $10 \%$. And this $0.806 \%$ of increase in the removal percentage was found in the 1 hour of contact period. In other hand, the increment in the contact time also made an effective role in contaminant removal. It has been more with 3 hours of contact time when compared with an hour of contact. Among all the level of dosages, 6\% of dosage shows higher value of increase with respect to the contact time $(0.595 \%)$.

As the effect of contact time over the chromium removal percentage, the trend has been noted that, there was a gradual increment up to $0.049 \%$ in the removal property in the presence of $4 \%$ dosage of eucalyptus ash where all the other dosage levels shows the non-linear variation in the above same.

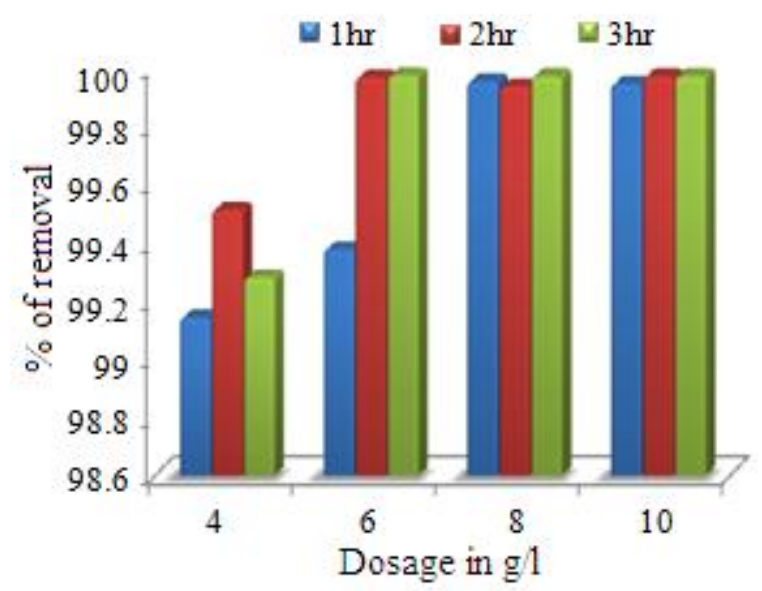

Figure.5 Removal of Chromium Percentage with Varying Dosage of Cow dung with $\mathrm{p}^{\mathrm{H}}$ of 6 
Table.4 Effect of Contact Time in the Removal of Chromium with $\mathrm{p}^{\mathrm{H}}$ of 6

\begin{tabular}{|c|c|c|c|}
\hline \multicolumn{4}{|c|}{ For the $\mathbf{p}^{\mathbf{H}}$ of 6 With Various Dosage Level } \\
\hline \multirow{2}{*}{ Dosage } & \multicolumn{3}{|c|}{ Contact Time } \\
\cline { 2 - 4 } & $\mathbf{1 ~ h r}$ & $\mathbf{2} \mathbf{~ h r}$ & $\mathbf{3 ~ h r}$ \\
\hline 4 & 99.142 & 99.511 & 99.28 \\
\hline 6 & 99.376 & 99.965 & 99.971 \\
\hline 8 & 99.951 & 99.934 & 99.968 \\
\hline 10 & 99.942 & 99.968 & 99.969 \\
\hline
\end{tabular}

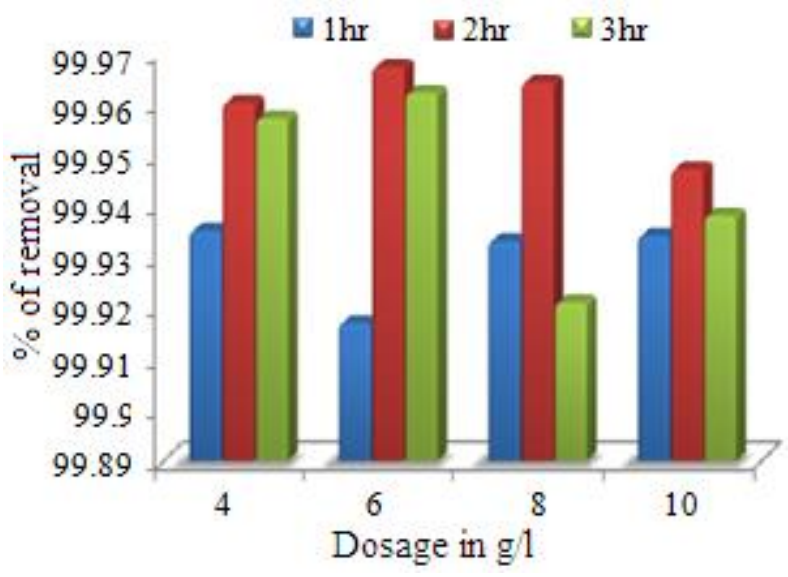

Figure.6 Removal of Chromium Percentage with Varying Dosage of Cowdung with $\mathrm{p}^{\mathrm{H}}$ of 7

Table 5. Effect of Contact Time in the Removal of Chromium with $\mathrm{p}^{\mathrm{H}}$ of 7

\begin{tabular}{|c|c|c|c|}
\hline \multicolumn{3}{|c|}{ For the $\mathbf{p}^{\mathbf{H}}$ of $\mathbf{7}$ With Various Dosage Level } \\
\hline \multirow{2}{*}{ Dosage } & \multicolumn{3}{|c|}{ Contact Time } \\
\cline { 2 - 4 } & $\mathbf{1} \mathbf{~ h r}$ & $\mathbf{2} \mathbf{~ h r}$ & $\mathbf{3} \mathbf{~ h r}$ \\
\hline 4 & 99.935 & 99.96 & 99.957 \\
\hline 6 & 99.917 & 99.967 & 99.962 \\
\hline 8 & 99.933 & 99.964 & 99.921 \\
\hline 10 & 99.934 & 99.947 & 99.938 \\
\hline
\end{tabular}

From the Fig. 6 and Table 5, it has been observed that the chromium contaminant has effectively removed from the aqueous solution by adding the Cow dung as an adsorbent. In precise the chromium content removal percentage has been increased from $99.935 \%$ to $99.957 \%$ for the dosage level of $4 \mathrm{~g} / \mathrm{l}$ from one hour to 3 hours of contact time. And for the $6 \mathrm{~g} / \mathrm{l}$ of dosage the removal has been increased up to $99.962 \%$ at 3 hours of contact period. In another way beyond the dosage of $6 \mathrm{~g} / \mathrm{l}$ the removal percentage doesn't revealed anymore significant variation in the removal. This is quiet differ from the $\mathrm{p}^{\mathrm{H}}$ level of 6 in all ways.In another way beyond the dosage of $6 \mathrm{~g} / \mathrm{l}$ the removal percentage doesn't revealed anymore significant variation in the removal. This is quiet differ from the $\mathrm{pH}$ level of 6 in all ways.

From the Figure 7 and Table 6, it has been noted that the chromium content removal percentage has been increased from $99.776 \%$ to $99.884 \%$ for the dosage level of $4 \mathrm{~g} / \mathrm{l}$ from one hour to 3 hours of contact time. Similarly it has been increased from $99.958 \%$ to $99.964 \%$ for $6 \mathrm{~g} / \mathrm{l}, 99.966 \%$ to $99.976 \%$ for $8 \mathrm{~g} / \mathrm{l}$ and finally 99.935 to $99.958 \%$ for $10 \mathrm{~g} / \mathrm{l}$. but in the other view for the higher time of contact 3 hours the chromium content removal has found increased with increase in the dosage level from $4 \mathrm{~g} / \mathrm{l}$ to $8 \mathrm{~g} / \mathrm{l}$. beyond the limit the removal percentage has decreased.

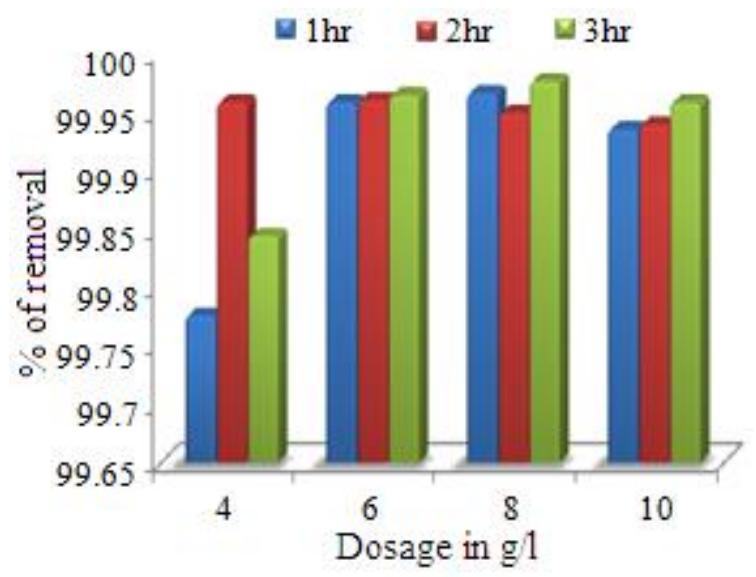

Figure.7 Removal of Chromium Percentage with Varying Dosage of Cow dung with $\mathrm{p}^{\mathrm{H}}$ of 8

Table 6. Effect of Contact Time in the Removal of Chromium with $\mathrm{p}^{\mathrm{H}}$ of 8

\begin{tabular}{|c|c|c|c|}
\hline \multirow{2}{*}{ For the $\mathbf{p}^{\mathbf{H}}$ of $\mathbf{8}$ With Various Dosage Level } \\
\hline \multirow{3}{*}{ Dosage } & \multicolumn{3}{|c|}{ Contact Time } \\
\cline { 2 - 4 } & $\mathbf{1} \mathbf{~ h r}$ & $\mathbf{2} \mathbf{~ h r}$ & $\mathbf{3} \mathbf{~ h r}$ \\
\hline 4 & 99.776 & 99.958 & 99.844 \\
\hline 6 & 99.958 & 99.96 & 99.964 \\
\hline 8 & 99.966 & 99.949 & 99.976 \\
\hline 10 & 99.935 & 99.939 & 99.958 \\
\hline
\end{tabular}




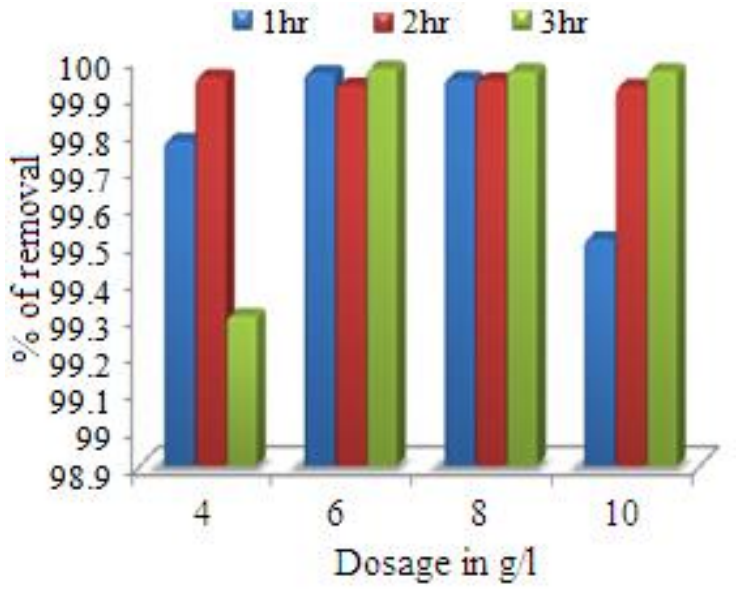

Figure.8 Removal of Chromium Percentage with Varying Dosage of Cow dung with $\mathrm{p}^{\mathrm{H}}$ of 9.2

Table 7. Effect of Contact Time in the Removal of Chromium with $\mathrm{p}^{\mathrm{H}}$ of 9.2

\begin{tabular}{|c|c|c|c|}
\hline \multirow{2}{*}{ For the $\mathbf{p}^{\mathrm{H}}$ of 9.2 With Various Dosage Level } \\
\hline \multirow{2}{*}{ Dosage } & \multicolumn{3}{|c|}{ Contact Time } \\
\cline { 2 - 4 } & $\mathbf{1 ~ h r}$ & $\mathbf{2} \mathbf{~ h r}$ & $\mathbf{3} \mathbf{~ h r}$ \\
\hline 4 & 99.776 & 99.948 & 99.304 \\
\hline 6 & 99.958 & 99.924 & 99.97 \\
\hline 8 & 99.942 & 99.938 & 99.963 \\
\hline 10 & 99.511 & 99.921 & 99.964 \\
\hline
\end{tabular}

From the Figure 8 and Table 7,it has been found that the chromium content removal percentage for the constant $\mathrm{p}^{\mathrm{H}}$ level of 9.2 with respect to the contact time has doesn't shown any clear pattern for the minimum dosage level of $4 \mathrm{~g} / \mathrm{l}$. but in the next increment in the dosage $6 \mathrm{~g} / \mathrm{l}$ with respect to the contact time shown a little increment of $0.027 \%$. In the next level of dosages such as $8 \mathrm{~g} / \mathrm{l}$ and $10 \mathrm{~g} / \mathrm{l}$ the value got decreased compared with $6 \mathrm{~g} / \mathrm{l}$.

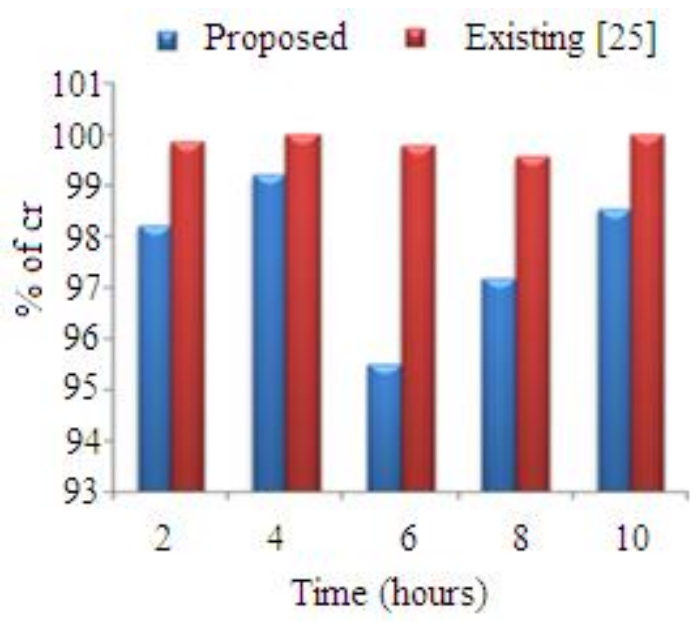

Figure.9 Removal of Chromium Percentage comparison
Table 8. Cr removal comparison

\begin{tabular}{|c|c|c|}
\hline Time(hrs) & Proposed & Existing [25] \\
\hline 2 & 98.23 & 99.85 \\
\hline 4 & 99.21 & 100 \\
\hline 6 & 95.52 & 99.8 \\
\hline 8 & 97.2 & 99.56 \\
\hline 10 & 98.55 & 100 \\
\hline
\end{tabular}

Figure 9 and table 8 shows the comparative analysis of our research work and existing [25] analysis by tea waste. The equilibrium was obtained after 50 minutes. Therefore, the adsorption for 50 minutes could be considered for whole batch experiments. Tea squander adsorbed chromium particles best at lower $\mathrm{Cr}$ fixation in the scope of 40 to $50 \mathrm{mg} / \mathrm{L}$ however the evacuation productivity dropped to $19 \%$ when the metal focuswas expanded to $70 \mathrm{mg} / \mathrm{L}$.

\section{Conclusion}

In the section, removal of chromium from industrial wastewater by using cow dung ash as low adsorbents is analyzed. The collected chromium contaminated waste water from the industry will have only a particular $\mathrm{Cr}^{+}$concentration and $\mathrm{p}^{\mathrm{H}}$ value, an aqueous solution has been prepared with unique concentration and with different $\mathrm{p}^{\mathrm{H}}$ values. From the figures and tables the removal of chromium is shown. The result shows that the Cow dung ash has effectively removed the chromium content when it was added $6 \mathrm{~g} / \mathrm{l}$ to the $1000 \mathrm{ml}$ of aqueous solution. In the view of contact time of the adsorbent, 3 hours of period been an ideal one and $\mathrm{p}^{\mathrm{H}}$ doesn't had a significant effect. In future the other low adsorbent material is used to remove the chromium from the industrial waste water it is better than this cow dung ash.

\section{Reference}

[1] I. Urruzola, L. Serrano, R. L. Ponte, Á. D. Andres, and J. Labidi, "Obtaining of eucalyptus microfibrils for adsorption of aromatic compounds in aqueous solution", Journal of chemical engineering, Vol. 229, pp. 42-49, 2013.

[2] J. Aravind, P. Kanmani, A. J. Devisri, S. Dhivyalakshmi and M. Raghavprasad, "Equilibrium and kinetic study on chromium (VI) removal from simulated waste water using gooseberry seeds as a novel biosorbent", Journal of environmental science and technology, Vol. 1, No. 3, pp. 233-244, 2015. 
[3] J. B. Dima, C. Sequeiros and N. E. Zaritzky, "Hexavalent chromium removal in contaminated water using reticulated chitosan micro/nanoparticles from seafood processing wastes", Journal of Chemosphere, Vol. 141, pp. 100-111, 2015.

[4] B. Wionczyk, W. Apostoluk, W. A. Charewicz and Z. Adamski, "Recovery of chromium (III) from wastes of uncolored chromium leathers, Part I. Kinetic studies on alkaline hydrolytic decomposition of the wastes", Journal of separation and purification technology, Vol. 81, pp.223-236, 2011.

[5] E. Agrafioti, D. Kalderis and E. Diamadopoulos, "Arsenic and chromium removal from water using biochars derived from rice husk, organic solid wastes and sewage sludge", Journal of environmental management, Vol. 133, pp. 309314, 2014.

[6] M. H. Dehghania, D. Sanaei, I. Ali, and A. Bhatnagar, "Removal of chromium (VI) from aqueous solution using treated waste newspaper as a low-cost adsorbent: Kinetic modeling and isotherm studies", Journal of molecular liquids, Vol. 215, pp. 671-679, 2016.

[7] H. Singh and V. K. Rattan, "Comparison of Hexavalent Chromium Adsorption from Aqueous Solutions by Various Biowastes and Granulated Activated Carbon", Journal of indian chemical engineering, Vol. 56 No. 1, pp. 12-28, 2014.

[8] S. Pal, P. Dhanpal, J. L. Goswami and P. K. Tewari, "Feasibility study of novel sorbent for chromium sequestration and enhanced immobilization", Journal of desalination and water treatment, Vol. 38, pp. 215-221, 2012.

[9] M. Jaina, V. K. Garg and K. Kadirvelu, "Adsorption of hexavalent chromium from aqueous medium onto carbonaceous adsorbents prepared from waste biomass", Journal of environmental management, Vol. 91, pp. 949957, 2010.

[10] N. S. Barot and H. K. Bagla, "Eco-friendly waste water treatment by cow dung powder (Adsorption studies of $\mathrm{Cr}$ (III), $\mathrm{Cr}$ (VI) and $\mathrm{Cd}$ (II) using tracer technique)", Journal of desalination and water treatment, Vol. 38, No. 1-3, pp. 104-113, 2012.

[11] N. S. Barot and H. K. Bagla, "Studies on biosorption of $\mathrm{Cr}(\mathrm{VI})$ on a green resin: dry cow dung powder and tracer technique", Journal of chromium toxicity or biosorption, pp. 1-10, 2012.

[12] T. D. Yavini, K. Silas, M. B. Grema and J. A. Luria, "Kinetic Study of Agricultural Wastes Conversion to Biogas using Cow Dung/Poultry
Droppings as Inoculums", Journal of environmental science, toxicology and food technology, Vol. 8, pp. 46-51, 2014.

[13] O. C. Ozor, M. V. Agah, K. I. Ogbu, A. U. Nnachi, O. E. Udu-ibiam and M. M. Agwu, "Biogas Production Using Cow Dung from Abakaliki Abattoir in South-Eastern Nigeria", Journal of scientific and technology, Vol. 3, No. 10, pp. 1-3, 2014.

[14] Oladejo, S. Oladipupo and B. F. Ayorinde, "Production of Bio Fertilizer from Rice Waste, Cow Dung and Timber Sawdust", Journal of chemical, environmental \& biological sciences, Vol.3, No. 2, pp.112-118, 2015.

[15] K. K. Gupta, K. R. Aneja and D. Rana, "Current status of cow dung as a bioresource for sustainable development", Journal of bioresources and bioprocess technology, Vol. 3, No. 1, pp. 1-11, 2016.

[16] V. Vinodhini, V. Anabarasu and D. Nilanjana, "Screening of natural waste products for the removal of $\mathrm{Cr}$ (VI) ions from industrial effluents", Journal of natural products and resources, Vol. 1, No. 2, pp. 174-180, 2010.

[17] M. B. Ibrahim and W. L. Jimoh, "Remediation of $\mathrm{Cr}$ and $\mathrm{Fe}$ from aqueous solution by natural adsorbents", Journal of biological and chemical sciences, Vol. 5, No. 3, pp. 915-922, 2011.

[18] K. Bhavsar and P. Patel, "Efficiency Evaluation of Tea Waste for Adsorption of Hexavalent Chromium from Industrial Effluent", Journal of science and research, pp.1-3, 2012.

[19] A. T. Ojedokun and O. S. Bello, "Sequestering heavy metals from wastewater using cow dung", Journal of water resources and industry, Vol. 13, pp. 7-13, 2016.

[20] M. Kaur, S. Mor and K. Ravindra, "Removal of Chemical Oxygen Demand from Landfill Leachate using Cow-dung Ash as a Low-cost Adsorbent", Journal of colloid and interface science, Vol. 469, pp. 338.343, 2016.

[21] M. I. Alfaa, D. B. Adie, S. B. Igboro, U. S. Oranusi, S. O. Dahunsi and D. M. Akali, "Assessment of biofertilizer quality and health implications of anaerobic digestion effluent of cow dung and chicken droppings", Journal of renewable energy, Vol. 63, pp. 681-686, 2014.

[22] P. Mullai, S. K. Nayaki, M. K. Yogeswari and R. Nirmala, "Adsorption of Chromium (VI) From Aqueous Solution onto Bio-Organic Waste in Batch Reactors -An Equilibrium Study", Journal of chemical technology and research, Vol. 6, No. 12, pp. 4964-4969, 2014.

[23] G. Corro, L. Paniagua, U. Pal, F. Banuelos and M. Rosas, "Generation of biogas from coffee- 
pulp and cow-dung co-digestion Infrared studies of postcombustion emissions", Journal of energy conversion and management, Vol. 74, pp. 471- 481, 2013.

[24] A. Gunnar, L. Benhabyles and S. Igoud, "Energetic Valorization of Biomethane Produced from Cow-Dung", Journal of procedia engineering, Vol. 33, pp. 330-334, 2012.

[25]B. Saritha, M. K. Sathish and R. V. Arunrajkumar, "Experimental Study of Tea Waste as Adsorbent in Removal of Chromium (Vi) from Aqueous Solution", International Journal of Engineering Trends and Technology, Vol. 2, No. 2, pp. 8-10, 2011. 